\title{
THE INFLUENCE OF CERTAIN LIPIDS AND PROTEINS ON THE EFFECT OF TETANUS TOXIN IN MICE
}

\author{
A. W. Pound \\ Department of Pathology, The University of Queensland, Brisbane, Australia
}

A LIPID from tubercle bacilli, and to a lesser extent a synthetic lecithin, augment the immunisation of mice by tetanus toxoid (Pound, 1970). This is similar to the adjuvant effect of the tubercle bacillary lipid on antibody production in guinea-pigs when tubercle bacillary protein, ovalbumin or horse serum albumin was the antigen used (Pound, 1955, 1958).

The adjuvant effect may perhaps be due to the formation of a lipid-protein complex which is more effective as an antigen than the protein alone. The demonstration of a toxoid-lipid complex presents technical difficulties. However, a similar complex perhaps forms with tetanus toxin, and a difference between the responses of mice given an injection of toxin alone and of toxin mixed with lipid might provide an index of its formation. It has been reported that tetanus toxin is "potentiated" by lecithin and other materials (for example, Marie, 1914; Traub, Hollander and Friedemann, 1946); others have denied that this occurs.

The experiments reported below were carried out to examine this possibility.

\section{MATERIALS AND METHODS}

\section{Materials}

Mice. "Hall" strain mice of weight 26-30 g were used.

Tetanus toxin. A single sample of tetanus toxin, $40 \mathrm{Lf}$ per $\mathrm{ml}$ (C.S.L., Melbourne) was used throughout.

Tubercle bacillary lipid. This was prepared from heat-killed Mycobacterium tuberculosis, human strain P.N., by the method of extraction for the " hard wax" fraction (Anderson, 1927). The lipid was emulsified by grinding with isotonic saline; after coarse particles had settled the supernatant emulsion was used.

Lecithin. Synthetic L- $\alpha$-myristoyl lecithin (La Motte Chemical Products Co., Baltimore, Md., USA) was emulsified by shaking with warm isotonic saline. While warm, the emulsion was fairly stable, but on cooling lecithin separated as a fine flocculum. It seemed likely that the lecithin coated the containing vessel, the surface of which became unwettable even if the emulsion was replaced by saline.

Peptone-saline. A solution of 2 per cent. peptone (Difco Bacto Peptone, Batch no. 339) in isotonic saline autoclaved for $15 \mathrm{~min}$. at $121^{\circ} \mathrm{C}$.

Gelatin-saline. A solution of 2 per cent. gelatin (Oxoid Gelatin, Batch no. 4245) in isotonic saline autoclaved for $15 \mathrm{~min}$. at $121^{\circ} \mathrm{C}$.

Isotonic saline. A solution of 0.9 per cent. AR sodium chloride in distilled water autoclaved for $20 \mathrm{~min}$. at $121^{\circ} \mathrm{C}$; the $p \mathrm{H}$ of different batches was from 5.0 to 6.4 .

Glass beads. Soda glass Ballotini beads $0.1 \mathrm{~mm}$ in average diameter were washed with detergent, followed, after a thorough water wash, by treatment for $10 \mathrm{~min}$. with aqua regia. They were then washed repeatedly with distilled water and dried at $110^{\circ} \mathrm{C}$.

Glassware. Glassware was prepared in the same manner as the glass beads.

Received 16 Dec. 1969; accepted 2 Mar. 1970.

J. MED. MICROBIOL.- VOL. 3 (1970) 


\section{Experimental details}

The toxin was diluted with saline unless otherwise indicated in the protocols.

"Doubling dilutions" means a dilution series prepared by adding a sample of a preceding dilution to an equal volume of diluent in the ordinary manner. "Straight dilutions" were prepared by adding a measured quantity of an initial dilution to a measured quantity of diluent.

Pipettes used to dilute toxin and syringes were rinsed thoroughly with the diluted toxin being transferred, to equilibrate the toxin with the glass surface. Diluted toxin was not allowed to run down the sides of vessels. Great care was found to be necessary to avoid agitation or a free fall of diluted toxin through air, and to avoid bubbles.

Injections of $0.25 \mathrm{ml}$ or larger were made with a tuberculin syringe. Smaller quantities were injected with a Micrometer Syringe. A separate syringe was used for each diluted toxin.

Toxin was diluted in the ways indicated above as set out in the individual experiments. Without delay, $0.5 \mathrm{ml}$, or occasionally other amounts as indicated, of each dilute toxin was injected in the muscles of the right gluteal region of randomly selected groups of 10 or sometimes 20 mice. The mice were then inspected at $15-\mathrm{min}$. intervals to $24 \mathrm{hr}$, at $30-\mathrm{min}$. intervals to the 48th $\mathrm{hr}$, then at appropriately longer intervals for signs of tetanus, up to 10 days. The time of death was recorded, and the mean calculated.

In experiments 1 and 2 each animal was weighed. As weight was not correlated with survival time weighing was discontinued in later experiments.

Experiment 1. From original toxin a 1 in 100 dilution was prepared and from this a 1 in 1000 dilution was made. Dilution series were then established $(a)$ by the doubling dilution technique from the 1 in 1000 stock dilution and $(b)$ by the straight dilution technique from the 1 in 100 stock.

Experiment 2. From original toxin diluted 1 in 50 a stock dilution of 1 in 500 was prepared. From this, straight dilutions were prepared $(a)$ in saline; $(b)$ and $(c)$ in saline containing $0.1 \mathrm{mg}$ or $1.0 \mathrm{mg}$ tubercle bacillary lipids per $0.5 \mathrm{ml}$ final dilution; $(d)$ and $(e)$ in saline containing lecithin 0.1 or $1.0 \mathrm{mg}$ per $0.5 \mathrm{ml}$ final dilution.

Experiment 3. From toxin initially diluted 1 in 100 straight dilutions of 1 in 1000 , 1 in 2000, etc., were prepared: $(a)$ and $(c)$ in vessels previously treated with a 0.2 per cent. emulsion of tubercle bacillary lipid or lecithin respectively, rinsed and washed once with cold water; $(b)$ in saline containing $1 \mathrm{mg}$ lecithin to each $0.5 \mathrm{ml}$ of final dilution and $(d)$ in saline containing tubercle bacillary lipid $1 \mathrm{mg}$ to each $0.5 \mathrm{ml}$.

Experiment 4. Doubling dilutions of the toxin, 1 in 500, 1 in 1000, etc., were prepared and dispensed in six lots. Lots $(a)$ and $(b)$ received an equal volume of saline; lot $(c)$ an equal volume of lecithin emulsion $(4 \mathrm{mg}$ per $\mathrm{ml}$ saline), lot $(d)$ lecithin emulsion $(0.4 \mathrm{mg}$ per $\mathrm{ml}$ saline); lot $(e)$ saline containing $4 \mathrm{mg}$ tubercle bacillary lipids per $\mathrm{ml}$; and lot $(f)$ saline containing $0.4 \mathrm{mg}$ tubercle bacillary lipid per $\mathrm{ml}$, so that the final dilutions of toxin were 1 in 1000,1 in 2000, etc., and the lipid concentrations were $1 \mathrm{mg}$ and $0.1 \mathrm{mg}$ to each $0.5 \mathrm{ml}$. Mice given an injection of lot $(b)$ were also given a subcutaneous injection of $1 \mathrm{mg}$ tubercle bacillary lipid in $0.5 \mathrm{ml}$ saline.

Experiment 5. From an initial 1 in 100 dilution of toxin, straight dilutions of 1 in 1000, 1 in 2000 , etc., were prepared $(a)$ in saline, and $(b),(c)$ and $(d)$ in saline containing 0.001 , 0.01 and 0.1 part by volume of guinea-pig serum. Mice were as usual given an injection of $0.5 \mathrm{ml}$ of each dilution. To the saline dilution $(a)$ was then added 0.1 part by volume of guinea-pig serum to give sample $(e) ; 0.55 \mathrm{ml}$ of this was injected into mice and their survival times were determined.

Experiment 6. Doubling dilutions of toxin, 1 in 500, 1 in 1000 , etc., were prepared and dispensed in triplicate. To lot $(a)$ were added equal volumes of saline, and to lot $(b)$ equal volumes of 1 in 50 guinea-pig serum and to lot $(c)$ equal volumes of 1 in 5 guinea-pig serum to give final dilutions of 1 in 1000, 1 in 2000, etc., of toxin and 1 in 100 and 1 in 10 guineapig serum respectively.

Experiment 7. A 1 in 500 dilution of toxin was made. From this straight dilution 
were made in (a) saline, $(b)$ saline containing 2 per cent. gelatin, $(c)$ saline containing 2 per cent. peptone and $(d)$ saline containing 1 in 10 guinea-pig serum.

Experiment 8. Groups of mice were given an injection of $1 \mathrm{ml}$ or $0.5 \mathrm{ml}$ of undiluted toxin, alone or with $1 \mathrm{mg}$ tubercle bacillary lipid or $1 \mathrm{mg}$ lecithin added as a concentrated emulsion, the volume injected being adjusted accordingly. Other groups received an injection of $0.25 \mathrm{ml}, 0.125 \mathrm{ml}$, or $0.004 \mathrm{ml}$ of undiluted toxin, or of $0.5 \mathrm{ml}$ of toxin diluted 1 in 2,1 in 4 , 1 in 125,1 in 250,1 in 500 and 1 in 1000 in saline, in saline containing $1 \mathrm{mg}$ tubercle bacillary lipid to each $0.5 \mathrm{ml}$, in saline containing $1 \mathrm{mg}$ lecithin to each $0.5 \mathrm{ml}$ or in saline containing 1 in 10 serum.

Experiment 9. A 1 in 1000 dilution of toxin was made, and from this straight dilutions were made $(a)$ in saline, $(b)$ in saline containing tubercle bacillary lipid, $1 \mathrm{mg}$ to $0.5 \mathrm{ml}$, and (c) in saline containing lecithin, $1 \mathrm{mg}$ to $0.5 \mathrm{ml}$. Mice received an injection of $0.5 \mathrm{ml}$ of each dilution and of diminishing volumes of the 1 in 1000 dilution in saline.

Experiment 10. A 1 in 1000 dilution of toxin was made. From this straight dilutions were prepared $(a)$ in saline and $(b)$ in saline containing 1 in 10 serum. Mice received an injection of $0.5 \mathrm{ml}$ of the serial dilutions and of measured quantities of the 1 in 1000 dilution.

Experiment 11. 30-ml quantities of toxin dilutions approximately 1 in 500,1 in 1000 , 1 in 4000 were prepared and $0.5 \mathrm{ml}$ of each was injected into mice. $1.2 \mathrm{ml}$ of Ballotini beads were added to the remaining $20 \mathrm{ml}$; the mixture was rotated gently to stir up the beads. When the beads settled similar injections were made into mice. The diluted toxins were decanted and the beads drained on filter paper. The beads from a 1 in 500 and two of the 1 in 4000 dilutions were extracted with $10 \mathrm{ml}$ of an emulsion of 0.1 per cent. tubercle bacillary lipid in saline, $5 \mathrm{ml}$ of 1 in 10 guinea-pig serum in saline and $5 \mathrm{ml}$ of a $0 \cdot 1$ per cent. emulsion of lecithin in saline respectively, and $1 \mathrm{ml}$ of each extract was injected into mice. Beads from the 1 in 500 and 1 in 4000 dilutions that had been extracted and beads from the 1 in 4000 dilutions that had not been extracted were injected into groups of three mice, approximately $0.4 \mathrm{ml}$ of beads into each mouse.

Experiment 12. Four $50-\mathrm{ml}$ quantities of toxin diluted 1 in 1000,1 in 2000,1 in 8000 and 1 in 32,000 approximately were prepared; $0.5 \mathrm{ml}$ volumes were injected into mice immediately, after they had been allowed to stand 1 and $2 \mathrm{hr}$ at room temperature; $0.5 \mathrm{ml}$ of the two higher dilutions were injected after agitation by 50 inversions of the closed bottles.

Experiment 13. Toxin diluted 1 in 4000 was dispensed in three vessels, and air, nitrogen or hydrogen was bubbled through at a rate of about 5 to 10 bubbles a second for $10 \mathrm{~min}$.; $0.5 \mathrm{ml}$ of each diluted toxin was injected into mice before and after treatment.

Experiment 14. $25-\mathrm{ml}$ samples of toxins diluted 1 in 1000 and 1 in 4000 were prepared in triplicate. To one triplicate was added $1 \mathrm{mg}$ lecithin per $\mathrm{ml}$, and to a second $1 \mathrm{mg}$ tubercle bacillary lipid per $\mathrm{ml} ; 0.5 \mathrm{ml}$ volumes of each diluted toxin were injected into mice at once, and after centrifugation at 5000 r.p.m. for $5 \mathrm{~min}$. to sediment the lipids. The supernates were removed and the lipid deposits taken up in $5 \mathrm{ml}$ saline; $0.5 \mathrm{ml}$ of each suspension was injected into mice.

\section{RESULTS}

Preliminary titration of the toxin by injecting doubling dilutions in saline into groups of ten mice had allowed an estimate of the MLD as $0.5 \mathrm{ml}$ of a 1 in 8000 dilution. However, it was found that mice challenged with $0.5 \mathrm{ml}$ of a 1 in 4000 straight dilution of the original toxin died in $26 \mathrm{hr}$ instead of the $48 \mathrm{hr}$ expected. This prompted a detailed comparison of dilution series prepared by the two methods.

There were considerable differences in survival times between the two series at the same dilution levels (table I). Thus toxins prepared by straight dilution were lethal at lower concentration and led to shorter survival times at the same concentration than toxins prepared by doubling dilution. There was no significant difference between male and female mice. 


\section{TABLE I}

Mean survival time of mice given injections of tetanus toxin diluted in saline (experiment 1 )

\begin{tabular}{|c|c|c|c|c|}
\hline \multirow{3}{*}{$\begin{array}{l}\text { Toxin } \\
\text { diluted } \\
1 \text { in }\end{array}$} & \multicolumn{4}{|c|}{$\begin{array}{l}\text { Mean survival time (hr) in mice* when the } \\
\text { toxin was made up by }\end{array}$} \\
\hline & \multicolumn{2}{|c|}{ doubling dilutions } & \multicolumn{2}{|c|}{ straight dilutions } \\
\hline & Male mice & Female mice & Male mice & Female mice \\
\hline $\begin{array}{r}100 \\
1000 \\
2000 \\
4000 \\
8000 \\
16,000 \\
32,000 \\
64,000\end{array}$ & $\begin{array}{l}\dddot{21} \\
24 \\
51 \\
- \\
- \\
-\end{array}$ & $\begin{array}{l}\dddot{21} \\
26 \\
49 \\
- \\
- \\
-\end{array}$ & $\begin{array}{l}11 \cdot 2 \\
20 \\
22 \\
29 \\
36 \\
48 \\
96 \\
190(4 S)\end{array}$ & $\begin{array}{c}\ldots \\
\ldots \\
\ldots \\
32 \\
\ldots \\
\ldots \\
104 \\
\ldots\end{array}$ \\
\hline
\end{tabular}

* In all tables each figure is based on experiments on groups of ten mice, except when other numbers are given. Survival times are usually to the nearest hour.

$4 S$, etc., states the number of survivors in a group; the figure before $4 S$ is the mean survival time of the mice that died. - Means that all the mice survived.

\section{TABLE II}

Survival time of mice given injections of straight dilutions of toxin in saline, in saline containing lipids, and in saline prepared in bottles treated with lipids

\begin{tabular}{|c|c|c|c|c|c|c|c|c|c|}
\hline \multirow{3}{*}{$\begin{array}{l}\text { Toxin } \\
\text { diluted } \\
1 \text { in }\end{array}$} & \multicolumn{9}{|c|}{ Mean survival time (hr) of mice used in } \\
\hline & \multicolumn{5}{|c|}{$\begin{array}{l}\text { experiment } 2^{*} \text {, in which the toxin dilutions } \\
\text { injected were made up in }\end{array}$} & \multicolumn{4}{|c|}{$\begin{array}{l}\text { experiment } 3^{*} \text {, in which the toxin dilutions } \\
\text { injected were made up in }\end{array}$} \\
\hline & $\begin{array}{c}(a) \\
\text { Saline }\end{array}$ & $\begin{array}{c}(b) \\
\text { Saline }+ \\
0.1 \mathrm{mg} \\
\text { TbL } \dagger \\
\text { per } \\
0.5 \mathrm{ml}\end{array}$ & $\begin{array}{c}(c) \\
\text { Saline }+ \\
1 \mathrm{mg} \\
\mathrm{TbL} \\
\text { per } \\
0.5 \mathrm{ml}\end{array}$ & $\begin{array}{c}(d) \\
\text { Saline }+ \\
0.1 \mathrm{mg} \\
\text { lecithin } \\
\text { per } \\
0.5 \mathrm{ml}\end{array}$ & $\begin{array}{c}(e) \\
\text { Saline+ } \\
1 \mathrm{mg} \\
\text { lecithin } \\
\text { per } \\
0.5 \mathrm{ml}\end{array}$ & $\begin{array}{l}(a) \\
\text { Saline in } \\
\text { vessels } \\
\text { pretreated } \\
\text { with } \\
\text { lecithin } \\
\text { emulsion }\end{array}$ & $\begin{array}{c}\text { (b) } \\
\text { Saline }+ \\
1 \mathrm{mg} \\
\text { lecithin } \\
\text { per } \\
0.5 \mathrm{ml}\end{array}$ & $\begin{array}{l}(c) \\
\text { Saline in } \\
\text { vessels } \\
\text { pretreated } \\
\text { with } \\
\text { TbL } \\
\text { emulsion }\end{array}$ & $\begin{array}{c}(d) \\
\text { Saline }+ \\
1 \mathrm{mg} \\
\text { TbL } \\
\text { per } \\
0.5 \mathrm{ml}\end{array}$ \\
\hline $\begin{array}{r}1000 \\
2000 \\
4000 \\
8000 \\
16,000 \\
32,000 \\
64,000 \\
128,000\end{array}$ & $\begin{array}{l}\ldots \\
24 \\
32 \\
47 \\
78 \\
-\ldots \\
\ldots\end{array}$ & $\begin{array}{l}\ldots \\
\ldots \\
29 \\
36 \\
52 \\
79 \\
\ldots \\
\ldots\end{array}$ & $\begin{array}{l}\ldots \\
\ldots \\
27 \\
34 \\
47 \\
74 \\
\ldots \\
\ldots\end{array}$ & $\begin{array}{l}\cdots \\
\ldots \\
28 \\
34 \\
45 \\
72 \\
\cdots \\
\cdots\end{array}$ & $\begin{array}{l}\ldots \\
\dddot{2} \\
28 \\
33 \\
48 \\
68 \\
\ldots \\
\ldots\end{array}$ & $\begin{array}{c}18 \\
21 \\
24 \\
29 \\
33 \\
45 \\
86 \\
130(1 S)\end{array}$ & $\begin{array}{r}22 \\
\dddot{32} \\
\dddot{47} \\
82 \\
120\end{array}$ & $\begin{array}{r}18 \\
21 \\
24 \\
30 \\
37 \\
44 \\
76 \\
186\end{array}$ & $\begin{array}{r}19 \\
20 \\
22 \\
32 \\
36 \\
48 \\
79 \\
136\end{array}$ \\
\hline
\end{tabular}

* Experiment 2, toxin diluted initially 1 in 50 , then to 1 in 500 in saline; experiment 3 , toxin diluted initially 1 in 100 in saline.

$\dagger \mathrm{TbL}=$ Tubercle bacillary lipid. 
Such differences must have arisen by loss or inactivation of toxin due to factors associated with the doubling dilution method. Preparation of doubling dilutions involves a greatly increased exposure of toxin to glass and air surfaces; losses due to adsorption may therefore have occurred.

\section{Influence of tubercle bacillary lipid and lecithin on the activity of tetanus toxin}

The above results must be allowed for in designing an experiment to test the influence of any agent on the effect of tetanus toxin in animals.

TABLE III

Survival times of mice given injections of doubling saline dilutions of toxin to which tubercle bacillary lipid or lecithin was added (experiment 4)

\begin{tabular}{|c|c|c|c|c|c|c|}
\hline \multirow[b]{2}{*}{$\begin{array}{l}\text { Toxin } \\
\text { diluted in } \\
\text { saline } \\
1 \text { in }\end{array}$} & \multicolumn{6}{|c|}{ Mean survival time (hr) of mice given stated saline dilution of toxin, with added saline } \\
\hline & $\begin{array}{l}\text { (a) } \\
\text { only }\end{array}$ & $\begin{array}{c}(b) \\
\text { only; separate } \\
\text { subcutaneous } \\
\text { injection of } \\
1 \mathrm{mg} \text { TbL in } \\
0.5 \mathrm{ml} \text { saline }\end{array}$ & $\begin{array}{c}(f) \\
+0.1 \mathrm{mg} \mathrm{TbL} \\
\text { per } 0.5 \mathrm{ml}\end{array}$ & $\begin{array}{c}(e) \\
+1 \mathrm{mg} \mathrm{TbL} \\
\text { per } 0.5 \mathrm{ml}\end{array}$ & $\begin{array}{c}(d) \\
+0.1 \mathrm{mg} \\
\text { lecithin } \\
\text { per } 0.5 \mathrm{ml}\end{array}$ & $\begin{array}{c}(c) \\
+1 \mathrm{mg} \\
\text { lecithin } \\
\text { per } 0.5 \mathrm{ml}\end{array}$ \\
\hline $\begin{array}{r}1000 \\
2000 \\
4000 \\
8000 \\
16,000\end{array}$ & $\begin{array}{l}22 \\
32 \\
65 \\
- \\
-\end{array}$ & $\begin{array}{l}23 \\
31 \\
59 \\
- \\
-\end{array}$ & $\begin{array}{l}22 \\
34 \\
68 \\
- \\
-\end{array}$ & $\begin{array}{l}21 \\
35 \\
67 \\
- \\
-\end{array}$ & $\begin{array}{l}22 \\
33 \\
70 \\
\\
\cdots\end{array}$ & $\begin{array}{l}23 \\
36 \\
67 \\
-\ldots\end{array}$ \\
\hline
\end{tabular}

Experiment 2 (table II) shows that when toxin was diluted in saline containing tubercle bacillary lipids or lecithin it gave shorter survival times at apparently equal doses, and was active at lower concentration, than when diluted in saline alone. Tubercle bacillary lipid and lecithin were equally effective, and the amount of lipid made no material difference within the limits used.

These results might suggest that the lipids activated the toxin. However, straight dilutions in saline made in vessels previously treated with either lipid did not differ in their toxic effect for mice from toxin diluted similarly in saline containing the lipids (experiment 3, table II). Further, the addition of either lipid to toxin already diluted in saline led to no alteration in the survival times of the mice (experiment 4, table III); and the lipids did not alter the progression of tetanus at different toxin levels, whether they were injected with the toxin or separately.

The toxin therefore is not activated. The results can be readily explained by a loss of toxin, when it is diluted in saline, that is reduced by the addition of lipid to the diluent or when the containing vessels are pretreated with lipid. It follows that the toxin postulated as lost must be removed from solution or else inactivated, and that the loss is reduced by some modification of the surface of the containing vessels by the lipids. 
The influence of serum, gelatin or peptone on the activity of diluted toxin

The addition of serum, gelatin or peptone to saline used to dilute tetanus toxin is reported to obviate some of the difficulties attending toxicity tests or to potentiate the toxin. This property appears to be similar to the effect of the lipids. Therefore it was examined in a similar series of experiments.

Experiment 5 (table IV) shows that when toxin was diluted in saline containing serum the survival times were shorter at similar dilution levels than when

TABLE IV

Survival times of mice given injections of toxin diluted in saline and in serum-saline, and of doubling dilutions of toxin in saline to which serum was added

\begin{tabular}{|c|c|c|c|c|c|c|c|c|}
\hline \multirow{3}{*}{$\begin{array}{l}\text { Toxin } \\
\text { diluted } \\
1 \text { in }\end{array}$} & \multicolumn{8}{|c|}{ Mean survival time (hr) of mice given in } \\
\hline & \multicolumn{5}{|c|}{$\begin{array}{l}\text { experiment } 5^{*} \text {, injections of straight } \\
\text { dilutions of toxin in }\end{array}$} & \multicolumn{3}{|c|}{$\begin{array}{l}\text { experiment } 6 \text {, injections } \\
\text { of doubling dilutions } \\
\text { in saline, with }\end{array}$} \\
\hline & $\begin{array}{c}(a) \\
\text { saline }\end{array}$ & $\begin{array}{c}(e) \\
\text { saline; } \\
1 \text { in } 10 \\
\text { serum } \\
\text { added }\end{array}$ & $\begin{array}{l}\text { (b) } \\
1 \text { in } 1000 \\
\text { serum } \\
\text { in saline }\end{array}$ & $\begin{array}{c}(c) \\
1 \text { in } 100 \\
\text { serum } \\
\text { in saline }\end{array}$ & $\begin{array}{l}(d) \\
1 \text { in } 10 \\
\text { serum } \\
\text { in saline }\end{array}$ & $\begin{array}{c}(a) \\
\text { saline } \\
\text { added } \\
\text { later }\end{array}$ & $\begin{array}{c}(b) \\
\text { serum } \\
\text { added to } \\
1 \text { in } 100 \\
\text { later }\end{array}$ & $\begin{array}{c}(c) \\
\text { serum } \\
\text { added to } \\
1 \text { in } 10 \\
\text { later }\end{array}$ \\
\hline $\begin{array}{r}1000 \\
2000 \\
4000 \\
8000 \\
16,000 \\
32,000 \\
64,000 \\
128,000\end{array}$ & $\begin{array}{r}20 \\
25 \\
34 \\
39 \\
67 \\
124 \\
-\ldots\end{array}$ & $\begin{array}{r}21 \\
24 \\
32 \\
41 \\
63 \\
113 \\
- \\
\ldots\end{array}$ & $\begin{array}{c}20 \\
26 \\
32 \\
35 \\
55 \\
98 \\
196(4 S) \\
\end{array}$ & $\begin{array}{c}19 \\
23 \\
27 \\
32 \\
39 \\
59 \\
110 \\
216(3 S)\end{array}$ & $\begin{array}{r}19 \\
23 \\
26 \\
33 \\
37 \\
54 \\
78 \\
156\end{array}$ & $\begin{array}{c}23 \\
36 \\
58 \\
(7 S) \\
- \\
- \\
\ldots\end{array}$ & $\begin{array}{c}24 \\
39 \\
74 \\
(5 S) \\
- \\
- \\
\ldots \\
\ldots\end{array}$ & $\begin{array}{c}23 \\
37 \\
76 \\
(9 S) \\
- \\
- \\
\ldots \\
\ldots\end{array}$ \\
\hline
\end{tabular}

* In experiment 5 , the toxin was diluted initially 1 in 100 in saline.

the toxin was diluted in saline alone and that the toxin was lethal at lower concentration. One-tenth serum had the greatest effect and 1 in 1000 the least. However, when serum was added to already prepared diluted toxin in saline, either in straight dilutions (experiment $5 e$ ), or in doubling dilutions (experiment 6), there was no alteration in the survival times of the injected mice.

Similar results were obtained when the toxin was diluted in saline containing gelatin, or peptone, or serum (experiment 7, table V).

The effect of these materials in the diluting fluid is obviously similar to the effect of the lipid, and is probably due to reduction of losses of toxin that occur when it is diluted in saline alone.

The influence of lipid and serum with large doses of toxin

The addition of the lipids or serum to $1 \mathrm{ml}$ or $0.5 \mathrm{ml}$ doses of undiluted toxin led to no significant variation in the survival time of the injected mice. 
Nor did such additions make any significant difference to the survival times of mice given injections of toxin diluted 1 in 2,1 in 4,1 in 125,1 in 250, 1 in 500,

TABLE V

Survival time of mice given injections of toxin diluted in saline, 2 per cent. gelatin-saline, 2 per cent. peptone-saline and 1 in 10 guinea-pig serum in saline (experiment 7)

\begin{tabular}{c|c|c|c|c}
\hline & \multicolumn{3}{|c}{$\begin{array}{c}\text { Mean survival time }(\mathrm{hr}) \text { of mice given injections of } \\
\text { toxin diluted in } \\
\begin{array}{c}\text { Toxin* } \\
\text { diluted } \\
1 \text { in }\end{array}\end{array}$} & \multicolumn{3}{|c}{$\begin{array}{c}(a) \\
\end{array}$} & $\begin{array}{c}(b) \\
\text { saline }\end{array}$ & gelatin-saline & $\begin{array}{c}(c) \\
\text { peptone-saline }\end{array}$ & $\begin{array}{c}(d) \\
\text { serum-saline }\end{array}$ \\
\cline { 2 - 5 } & & & & $\ldots$ \\
2000 & 23 & $\ldots$ & $\ldots 4$ & 23 \\
4000 & 29 & 26 & 35 & 33 \\
8000 & 38 & 33 & 37 & 39 \\
16,000 & 55 & 42 & 96 & 54 \\
32,000 & 108 & 59 & 192 & 96 \\
64,000 & - & 81 & $170(4 S)$ & $206(2 S)$ \\
96,000 & $\ldots$ & 130 & & \\
128,000 & $\ldots$ & $180(5 S)$ & & \\
\hline
\end{tabular}

* Toxin diluted initially 1 in 500 in saline.

TABLE VI

Survival time of mice given injections of undiluted toxin, with or without lipids, and of high concentrations of toxin in saline, lecithin-saline, $\mathrm{Tb}$ lipid-saline or serum-saline (experiment 8)

\begin{tabular}{|c|c|c|c|c|c|c|c|c|}
\hline \multirow{2}{*}{$\begin{array}{l}\text { Undiluted } \\
\text { toxin } \\
\text { (ml) }\end{array}$} & \multicolumn{3}{|c|}{$\begin{array}{l}\text { Mean survival time }(\mathrm{hr}) \text { of } \\
\text { mice given this volume of } \\
\text { toxin plus }\end{array}$} & \multirow{2}{*}{$\begin{array}{l}\text { Toxint } \\
\text { diluted } \\
1 \text { in }\end{array}$} & \multicolumn{4}{|c|}{$\begin{array}{l}\text { Mean survival time (hr) of mice given } \\
0.5 \mathrm{ml} \text { of this dilution of toxin in saline }\end{array}$} \\
\hline & saline & Tb lipid & lecithin & & only & + Tb lipid & + lecithin & $\begin{array}{l}+ \text { serum } \\
\text { to } 1 \text { in } 10\end{array}$ \\
\hline $\begin{array}{l}1 \cdot 0 \\
0.5 \\
0.25 \\
0.125 \\
0.004 \\
0.002\end{array}$ & $\begin{array}{r}4 \cdot 5(5)^{*} \\
4 \cdot 8 \\
5 \cdot 6 \\
5 \cdot 8 \\
10 \cdot 4 \\
12 \cdot 2\end{array}$ & $\begin{array}{c}4 \cdot 2(4) \\
5 \cdot 3(5) \\
\ldots \\
\ldots \\
\ldots \\
\ldots\end{array}$ & $\begin{array}{c}4 \cdot 7(4) \\
5 \cdot 0 \\
\ldots \\
\ldots \\
\ldots \\
\ldots\end{array}$ & $\begin{array}{r}2 \\
4 \\
125 \\
250 \\
500 \\
1000\end{array}$ & $\begin{array}{c}\cdots \\
5 \cdot 1 \\
6 \cdot 3 \\
10 \cdot 1 \\
12 \cdot 0 \\
14 \cdot 2(20) \\
18 \cdot 0(20)\end{array}$ & $\begin{array}{c}\ldots \\
5 . . \\
6.0 \\
11 \cdot 1 \\
11 \cdot 5 \\
13 \cdot 9(20) \\
\ldots\end{array}$ & $\begin{array}{c}\ldots \\
5 \cdot \% \\
6 \cdot 3 \\
\ldots \\
12 \cdot 7 \\
\ldots \\
17 \cdot 0(20)\end{array}$ & $\begin{array}{c}\ldots \\
\ldots \\
5 \cdot 3(5) \\
5 \cdot 9 \\
10 \cdot 1 \\
12 \cdot 2 \\
14 \cdot 0(20) \\
17 \cdot 5(20)\end{array}$ \\
\hline
\end{tabular}

* The figures in brackets give the number of mice used, if it was not 10 .

$\dagger$ The dilutions contain in $0.5 \mathrm{ml}$ the same amount of original toxin as is given on the same line in the first column.

and 1 in 1000 in saline, in saline containing lipid or serum proteins, or given the equivalent amounts of undiluted toxin (experiment 8 , table VI).

Any loss of toxin at these dose levels is therefore less than could be estimated by these means and there is no evidence that the lipids or proteins had any effect on the potency of the toxin. 


\section{Quantitative aspects of the effect of lipids and serum proteins on diluted toxin}

If the loss of toxin is reduced when the saline in which it is diluted contains tubercle bacillary lipid, lecithin or proteins, a similar result should be expected

TABLE VII

Survival time of mice given injections of toxin diluted in saline, in saline containing lecithin, and in saline containing tubercle bacillary lipid, and of measured amounts of the initial dilution in saline (experiment 9 )

\begin{tabular}{c|c|c|c|c|c|c}
\hline & \multicolumn{2}{|c|}{$\begin{array}{c}\text { Mean survival time (hr) of mice } \\
\text { given } 0 \cdot 5 \text { ml of this dilution of } \\
\text { toxin in }\end{array}$} & \multicolumn{3}{|l}{ In mice given measured volumes of saline } \\
dilution 1 in $1000(d)$
\end{tabular}

* The number in brackets is the number of mice used when this differed from 10.

if the same amounts of toxin were administered by direct measurement of the initial dilution in saline (experiments 9 and 10), unless the loss was due to spontaneous deterioration of the toxin in the solution in saline alone.

The survival times of mice receiving measured amounts of the toxin directly from the initial dilution in saline were not only shorter than in mice treated with the corresponding straight dilutions in saline as expected, but were even shorter than in mice given the corresponding amount of toxin as a straight dilution made in saline containing the tubercle bacillary lipid, lecithin or serum proteins (tables VII and VIII).

The apparent activating effect of the lipids or serum proteins is clearly due to reduction of loss of toxin. Moreover, it is apparent that some loss must occur even when dilutions are made into saline containing the lipids or serum proteins, but agitation during dilution also may be significant here. 
Spontaneous deterioration of the toxin due to random chemical factors cannot account for the results, but in any case the stability of the toxin in dilute solution is shown in experiment 12 to be an insignificant factor.

The situation is best visualised from graphs of the variation of survival time with dose of toxin; the figure plots typical results. The results obtained by injection of measured amounts of the initial dilution allow the best estimate of the dose-response curve. The LD50 may be estimated from the data of

\section{TABLE VIII}

Survival time of mice given injections of toxin diluted in saline and in serum-saline, and of measured amounts of the initial dilution in saline (experiment 10)

\begin{tabular}{|c|c|c|c|c|}
\hline \multirow{2}{*}{$\begin{array}{l}\text { Straight } \\
\text { toxin } \\
\text { dilutions } \\
1 \text { in }\end{array}$} & \multicolumn{2}{|c|}{$\begin{array}{l}\text { Mean survival time (hr) of mice given } \\
\text { these straight dilutions from the } \\
1 \text { in } 1000 \text { dilution }\end{array}$} & \multicolumn{2}{|c|}{$\begin{array}{l}\text { In mice given a measured volume of } \\
\text { toxin diluted } 1 \text { in } 1000 \text { in saline }(c)\end{array}$} \\
\hline & $\begin{array}{c}\text { (a) } \\
\text { in saline }\end{array}$ & $\begin{array}{c}(b) \\
\text { in serum } \\
1 \text { in } 10 \text { in saline }\end{array}$ & $\begin{array}{l}\text { mean survival } \\
\text { time (hr) was }\end{array}$ & $\begin{array}{l}\text { volume injected } \\
\text { (ml) was }\end{array}$ \\
\hline $\begin{array}{r}1000 \\
2000 \\
4000 \\
8000 \\
16,000 \\
32,000 \\
48,000 \\
64,000 \\
96,000 \\
128,000 \\
192,000 \\
256,000\end{array}$ & $\begin{array}{l}\ldots \\
\ldots \\
29 \\
35 \\
52 \\
99 \\
- \\
- \\
\ldots \\
\ldots \\
\ldots\end{array}$ & $\begin{array}{l}\ldots \\
\ldots \\
25 \\
30 \\
35 \\
49 \\
53 \\
69 \\
87 \\
114 \\
169(2 S) \\
\ldots\end{array}$ & $\begin{array}{l}18 \cdot 2 \\
21 \cdot 6 \\
24 \\
24 \\
29 \\
36 \\
42 \\
53 \\
63 \\
91 \\
150(1 S) \\
264(9 S)\end{array}$ & $\begin{array}{l}0.5 \\
0.25 \\
0.125 \\
0.063 \\
0.031 \\
0.016 \\
0.01 \\
0.0075 \\
0.005 \\
0.004 \\
0.0025 \\
0.002\end{array}$ \\
\hline
\end{tabular}

table VII, column $d$, and table VIII, column $c$, by the method of Reed and Muench (1938) as $0.0022 \mathrm{ml}$ of the 1 in 1000 dilution in saline. It is clear that, when diluted in saline further than 1 in 1000 , a considerable proportion of the toxin is lost. The proportions lost at lower dilutions than this appear to be considerably less, and are perhaps insignificant. This may be ascribed to protection by other proteins, etc., in the crude toxin, the effect of which begins to be diluted out at dilutions of 1 in 1000 .

\section{Adsorption of toxin on glass beads}

If the loss of toxin occurs by adsorption to the surface of the containing vessels, the provision of a large glass surface, in the form of small glass beads, would be expected to increase the loss (experiment 11). As expected, when Ballotini beads were added to toxin diluted in saline, large amounts were either inactivated or removed (table IX). The surface area of the beads added is about $600 \mathrm{~cm}^{2}$, and it can be calculated that the amount of toxin adsorbed from the 1 in 500, 1 in 1000 and the 1 in 4000 dilutions would amount to about 30,7 and 1 LD50 per $\mathrm{cm}^{2}$ respectively. 


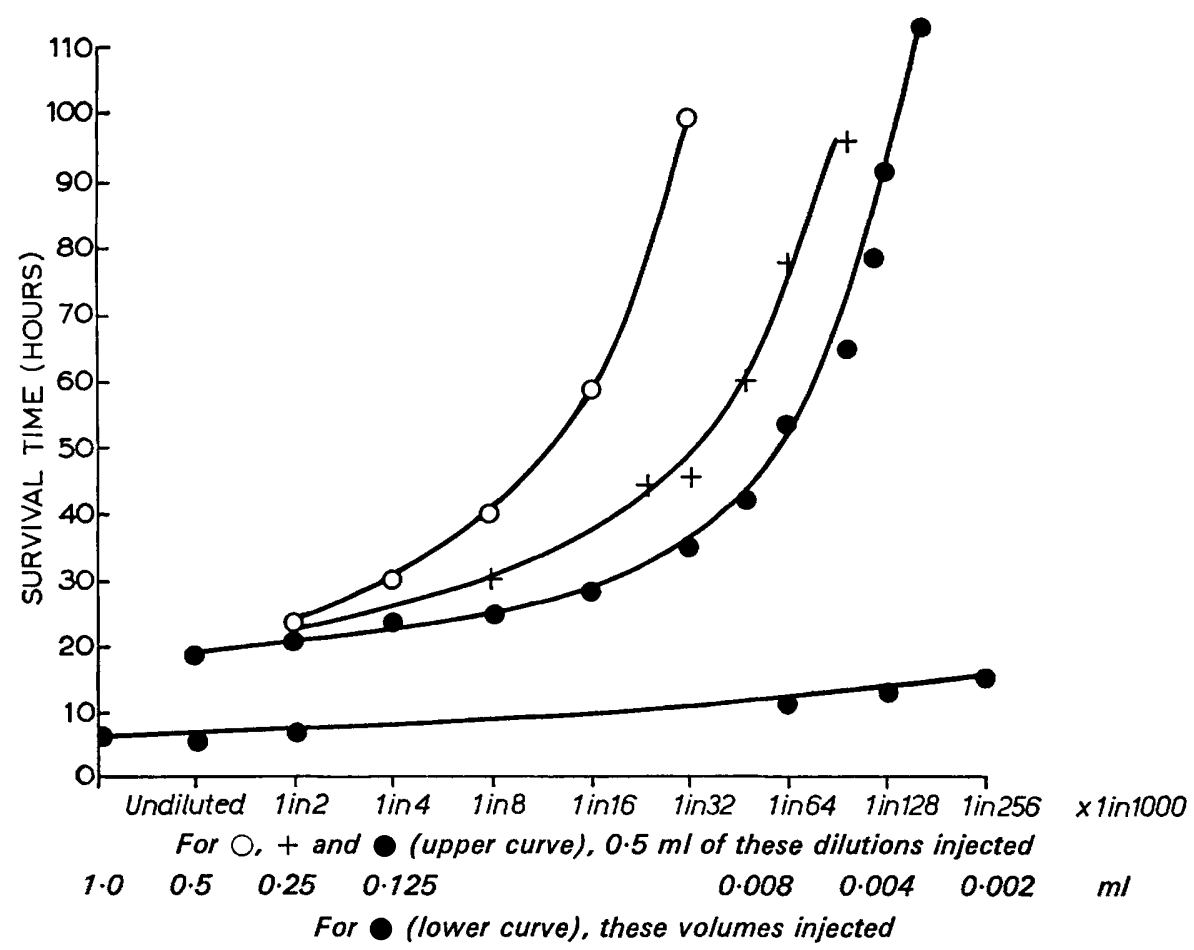

FIGURE.-Variation of mean survival times of mice given injections of a range of doses of tetanus toxin by different methods (see text).

Toxin given as straight dilution in saline. Combined data of table VII, column (a) and table VIII, column (a). + Toxin given as straight dilution in saline containing Tb lipid. Data of table VII, column (c). - Toxin given as measured quantities of a 1 in 1000 dilution of original toxin. Upper curve, combined data of table VII, column (d), and table VIII, column (c). Lower curve, data of table VI.

\section{TABLE IX}

Mean survival times of mice given injections of toxin diluted in saline before and after treatment with glass beads (experiment 11)

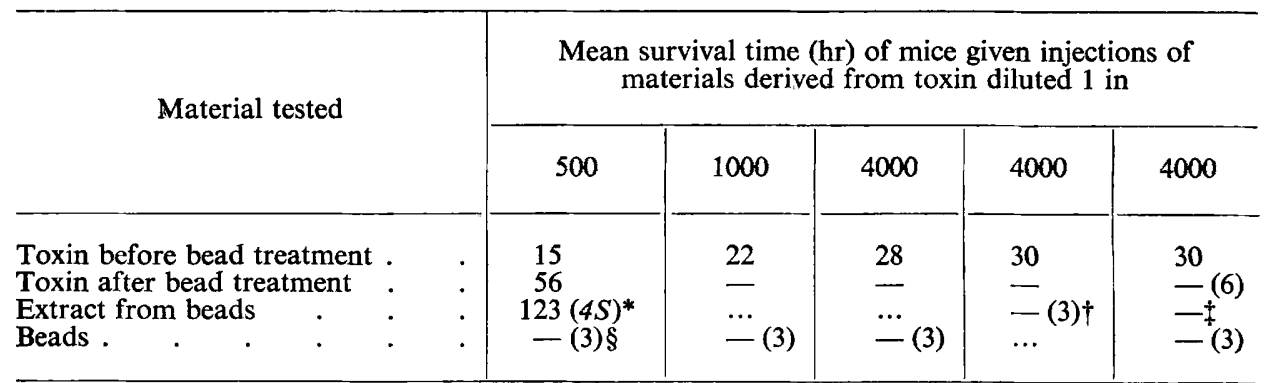

* Extracted with tubercle bacillary lipid emulsion; $\dagger$ extracted with serum-saline; $\ddagger$ extracted with lecithin emulsion.

$\S$ Numbers in brackets are the numbers of animals used, if this differs from 10. 
No animal into which the recovered beads were injected developed signs of tetanus, nor could significant amounts of toxin be extracted from the beads by lipid emulsions or by serum in saline. The adsorbed toxin was therefore either inactivated or held so strongly that it could not be eluted by these means or by the body fluids.

TABLE X

Mean survival times of mice given injections of tetanus toxin diluted in saline,

before and after standing and after agitation (experiment 12)

\begin{tabular}{|c|c|c|c|c|}
\hline \multirow{2}{*}{$\begin{array}{l}\text { Time toxin } \\
\text { dilution injected }\end{array}$} & \multicolumn{4}{|c|}{$\begin{array}{l}\text { Mean survival time (hr) of mice given } \\
\text { injections of toxin diluted approximately } 1 \text { in }\end{array}$} \\
\hline & 1000 & 2000 & 8000 & 32,000 \\
\hline $\begin{array}{l}\text { On dilution } \\
\text { After } 1 \mathrm{hr} \\
\text { After } 2 \mathrm{hr} \\
\text { After agitation }\end{array}$ & $\begin{array}{l}18 \\
\ldots \\
18 \\
\ldots\end{array}$ & $\begin{array}{l}22 \\
\ldots \\
20 \\
\ldots\end{array}$ & $\begin{array}{l}35 \\
38 \\
36 \\
-\end{array}$ & $\begin{array}{l}65 \\
69 \\
67 \\
-\end{array}$ \\
\hline
\end{tabular}

Clean beads adsorbed large amounts of toxin diluted in saline, but similar experiments showed that less was adsorbed when the beads were added to toxin diluted in saline containing serum; only small amounts were adsorbed when beads previously treated with serum were added to toxin diluted in saline. It

TABLE XI

Mean survival times of mice given injections of toxin diluted in saline before and after passage of gas bubbles (experiment 13)

\begin{tabular}{lr|c|c|c}
\hline \multirow{2}{*}{ Time of dilution } & \multicolumn{3}{|c}{$\begin{array}{c}\text { Mean survival time (hr) of mice given this } \\
\text { toxin when gas used for bubbling was }\end{array}$} \\
\cline { 2 - 5 } & air & nitrogen & hydrogen \\
\hline Before bubbling & $\cdot$ & 33 & 36 & 32 \\
After bubbling & $\cdot$ & $163(9 S)$ & - & $240(8 S)$ \\
\hline
\end{tabular}

is clear that serum proteins were adsorbed to the surface of the beads, modifying it so that the amount of toxin adsorbed was reduced.

\section{Stability of diluted toxin on standing and on agitation}

Spontaneous deterioration of diluted toxin could not, as is clear, account for the results obtained, but irregularities in results occurred if extreme care was not taken to avoid agitation or formation of bubbles in the solution. These factors were therefore examined (experiments 12 and 13), since it seemed that surface forces would be involved. 
No significant change was found in the survival times of mice given an injection of diluted toxin after the dilution had been allowed to stand still for $2 \mathrm{hr}$ at room temperature-i.e., no deterioration of toxin occurred (table X). However, mice given an injection of toxin ( 1 in 8000 or 1 in 32,000 in saline) that had been agitated all survived; the toxin was therefore inactivated.

Similarly, the passage of bubbles of air, nitrogen or hydrogen through diluted toxin inactivated it (table XI).

\section{Failure of adsorption of toxin to lipid particles}

The particles of lipid in the emulsions provide a considerable surface on which adsorption of toxin might occur, although if this was the case the toxin

TABLE XII

Survival times of mice given injections of toxin diluted in saline, and in saline containing lipids, before and after centrifugation, and of the sedimentable lipid

\begin{tabular}{|c|c|c|c|c|c|c|c|}
\hline \multirow{3}{*}{ Material tested } & & \multicolumn{6}{|c|}{$\begin{array}{c}\text { Mean survival time }(\mathrm{hr}) \text { of mice given injections } \\
\text { of materials derived from }\end{array}$} \\
\hline & & \multicolumn{3}{|c|}{ toxin diluted 1 in 1000 , with } & \multicolumn{3}{|c|}{ toxin diluted 1 in 4000 , with } \\
\hline & & $\begin{array}{l}\text { added } \\
\text { saline }\end{array}$ & $\begin{array}{l}\text { added } \\
\text { Tb lipid }\end{array}$ & $\begin{array}{l}\text { added } \\
\text { lecithin }\end{array}$ & $\begin{array}{l}\text { added } \\
\text { saline }\end{array}$ & $\begin{array}{l}\text { added } \\
\text { Tb lipid }\end{array}$ & $\begin{array}{l}\text { added } \\
\text { lecithin }\end{array}$ \\
\hline $\begin{array}{l}\text { Initial toxin }+ \text { added substance } \\
\text { The same, after centrifugation } \\
\text { Resuspended sediment }\end{array}$ & $\dot{.}$ & $\begin{array}{l}21 \\
24 \\
\ldots\end{array}$ & $\begin{array}{l}22 \\
24 \\
250(1 S)\end{array}$ & $\begin{array}{r}21 \\
23 \\
163\end{array}$ & $\begin{array}{l}28 \\
30 \\
\ldots\end{array}$ & $\begin{array}{l}31 \\
32 \\
-\end{array}$ & $\begin{array}{l}27 \\
29 \\
-\end{array}$ \\
\hline
\end{tabular}

was not inactivated. The results of experiment 14 (table XII) show that the survival time of mice given injections of toxins diluted in saline, with either lipid added, did not alter after the lipid had been centrifuged out, and that the sedimented lipids did not carry down significant amounts of toxin. The slight toxicity of the lipid deposits can be ascribed to residual supernate that could not be pipetted off.

\section{Discussion}

Earlier workers have reported that when tetanus toxin was diluted in saline containing various colloidal materials, for example, serum, broth or egg albumin (Ricketts and Kirk, 1906), tissue extracts or egg lecithin (Marie, 1914), peptone or broth (Condrea and Poenaru, 1933), serum or broth (Traub et al., 1946), it was apparently more toxic than when it was diluted in saline. Such results might suggest an "activation" or "potentiation" of the toxin or a pro-toxin, the interpretation put forward by early authors and maintained by Traub et al. Mutermilch, Belin and Salamon (1933b), who obtained similar results with peptone, horse serum or rabbit serum doubted, however, the possibility that the toxin could be activated by such a diverse range of materials, and suggested that these materials protected the toxin against oxidation or 
other chemical effects due to agitation during dilution. The passage of bubbles of oxygen or carbon dioxide inactivated the toxin; they ascribed this to chemical action and noted that serum proteins, broth or egg albumin in the diluent obviated these effects (Mutermilch et al., 1932, 1933a). Tetanus toxin was adsorbed to glass (Mutermilch et al., 1934), but the significance of this in relation to the previous findings was not followed up, and has since been overlooked. Halter (1936), Istrati (1938) and Benzoni (1947) considered that colloidal materials prevented a spontaneous deterioration of the toxin in dilute solution. Zuger, Hollander and Friedemann (1939) found no effect of lecithin on the toxicity of tetanus toxin in guinea-pigs, but important technical details were not given.

The present experiments confirm that when tetanus toxin diluted in saline containing a tubercle bacillary lipid, lecithin, serum proteins, gelatin or peptone was injected into mice, the mice died in shorter times and at lower concentration of toxin than when the toxin was diluted in saline alone. However, mice given injections of the corresponding measured amounts of the initial dilution in saline died in even shorter times. Further, when these materials were added to toxin already diluted in saline, the survival time of the mice into which the mixtures were injected did not change.

The toxin therefore was not activated or potentiated by these materials. On the contrary, the results suggest a loss of toxin to glass surfaces, for example, those of the containing vessels, that is reduced when the surface is treated first with the materials. In concentrated toxin, that is, not diluted beyond 1 in 1000 , the losses were small or insignificant, perhaps because of the presence of protein or other materials in the toxin.

Agitation or the passage of bubbles of gas through diluted toxin also inactivated it. Mutermilch et al. $(1932,1933 a)$ ascribed the inactivation of tetanus toxin by bubbles of oxygen or carbon dioxide to chemical action. However, since even inert gas (nitrogen or hydrogen) inactivated toxin, it seems evident that the inactivation was due to forces at the gas-liquid interfaces. Mutermilch et al. $(1932,1933 a)$, in effect, showed that the presence of serum proteins, broth or egg albumin in the diluent obviated these effects.

Spontaneous deterioration of toxin in dilute solution does not account for these results. In any case, diluted toxin was stable for periods of time greater than that between its preparation and its injection into mice. Nonetheless, the fact that toxin is adsorbed and inactivated at surfaces means that a slow, progressive inactivation of even concentrated toxin must occur in a manner similar to the slow denaturation of any native protein in solution.

I used a single preparation of tetanus toxin of high titre. Condrea and Poenaru commented that "potentiation " was found only with some preparations, in particular with high-titred toxins and ammonium sulphate-precipitated toxins. Traub et al. observed it only with some toxin preparations, but did not think it was related to the titre. They did not, as van Heyningen (1950) seems to imply, add colloidal materials to toxins already diluted in saline; they appear to have made initial dilutions in saline, and further diluted these in saline containing serum. Protection against loss of toxin in dilute solution 
seems to be the more probable explanation of their results. The behaviour of different preparations of toxin may be attributed to the variation in amount of protein and other constituents, the protective effect of which would be diluted out at different levels. "Potentiation" would be expected particularly with high titred or refined toxins, but even a high titred toxin containing a large amount of protein might still not display it.

Traub et al. put forward, as further evidence for potentiation of the toxin, the fact that more toxin, as measured by toxicity tests in mice, could sometimes be recovered from experimental animals than was injected. Abel, Evans and Hampil (1936) noted the same phenomenon. Traub et al. found that it occurred only with " potentiable" toxins. This result may also be attributed to loss of toxin during titration dilutions. Thus, it is usual to titrate the toxin by injection into mice of doubling dilutions in saline alone or in saline containing some colloid. Animals are then given an injection of a larger dose of toxin, not as a large volume of the highest dilution containing the MLD, but as a small volume of a lower dilution. Clearly, under these conditions a larger dose of toxin would be injected than estimated, and the excess might be considerable with a "potentiable" toxin (cf. experiment 1 in this paper).

Some other important experiments in which the effects of several tetanus toxin preparations, diluted to different levels, were compared, should be re-evaluated in the light of the protection by colloids against loss of toxin. Thus, differences in the relative toxicity of different preparations, titrated in differing animal species and by different routes in the same animal species, have been reported by Smith (1942-43), Friedemann and Hollander (1943) and others. The interpretation was that there are biological differences between individual toxins. However, physico-chemical investigation fails to disclose any such differences (Largier, 1956). Such differences may largely disappear when allowance is made for the losses of toxin that occur.

Most of the toxin may be lost when it is diluted in saline, and significant losses may occur even when it is diluted in saline containing various colloids. When doubling dilutions are made, the losses are additive from one dilution to the next. Pillemer (1946) found great difficulty in obtaining reliable results when titrating tetanus toxin in mice; he thought that this was due to adsorptive losses. Ramon et al. (1938a and $b$ ) observed that agitation of any kind or minor variations in technique of diluting toxin led to considerable differences in the results of toxicity tests; each additional manipulation of a diluted toxin led to an increase in survival time of the mice. Since adsorptive losses are involved, it seems probable that ionic constitution, ionic strength and $p \mathrm{H}$ of solutions, temperature, the iso-electric points of other colloids present and the physical characteristics of the glass of the vessels would be of importance. Indeed, Salamon, Mutermilch and Belin (1934) found little variation in the protection (" against oxidation ") of tetanus toxin by serum from $p \mathrm{H} 3 \cdot 6-8 \cdot 3$,

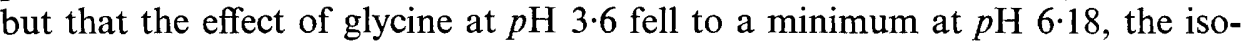
electric point of glycine. It does not follow that the toxin would be inactivated when adsorbed on all types of surface or in all conditions.

Since the tubercle bacillary lipid, lecithin or protein had no significant 
effect on the activity of the toxin when loss was prevented, the experiments offer no evidence for the formation of a complex. The crude tetanus toxin used probably contained protein and other materials and it is possible that the toxin was already present as some sort of complex. Pillemer and Wartman (1947) reported that mice given an injection of large doses of crystalline toxin died in $2 \mathrm{hr}$, whereas mice given similarly large doses of the crude toxin died in 4 to $5 \mathrm{hr}$; the difference might suggest that substances in the crude toxin slowed down the rate at which the toxin was adsorbed.

Peptone, serum and various tissue extracts or chemicals have been claimed to influence the effects of some other bacterial toxins. Thus, Dernby and Walbum (1923) found diphtheria toxin to be "potentiated" by peptone. Mutermilch et al. (1933a) concluded that small quantities of normal serum, pus, tissue extracts, egg albumin or peptone prevented "deterioration" of diphtheria toxin, although Zuger et al. (1939) found that some of these substances had no influence on this toxin. Maloney and Taylor (1932) showed that diphtheria toxin was adsorbed to glass surfaces and that serum reduced the amount adsorbed. Similarly, the potency of $\mathrm{Cl}$. botulinum toxin was found by Sommer and Sommer (1928), as well as by others, to be increased by diluting it in saline containing peptone, horse serum, protein hydrolysates or lecithin. Considerations similar to those applying with tetanus toxin reported in this paper would seem to apply to several other bacterial toxins.

\section{SUMMARY}

The effect of a tubercle bacillary lipid, lecithin and some proteins on the activity of tetanus toxin was measured by injecting them into mice with graded doses of the toxin and noting the survival times of the animals.

When the tetanus toxin was given as a set volume of a dilution in saline containing lipid or protein, it gave shorter survival times and was lethal at lower concentrations than when it was given as the same dilution in saline alone. However, the addition of lipid or protein to the toxin already diluted in saline alone had no influence on the survival times of the mice. Injection of the corresponding amount of toxin as a measured volume of the initial dilution gave even shorter survival times.

Tetanus toxin is adsorbed or inactivated at glass surfaces and is inactivated at gas-liquid interfaces. The losses from these causes are reduced in the presence of lipid or protein in the diluent or by treating the glass surfaces with these materials before they are brought into contact with diluted toxin.

The apparent activity of the lipids or proteins in activating the toxin is due to the reduction of such losses. No evidence was found of any direct effect on the activity of the toxin.

\section{REFERENCES}

Abel, J. J., Evans, E. A., ANd Hampil, 1936. Bull. Johns Hopkins Hosp., 59, 307. BETTYLEE

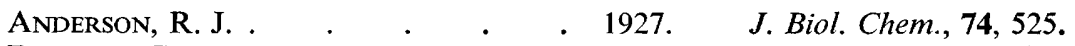

BENZONI, G. $\quad \cdot \quad \cdot \quad \cdot \quad \cdot \quad \cdot 1947 . \quad$ Riv. Ist. sieroter, ital., $22,70$.

J. MED. MICROBIOL.-VOL. 3 (1970) 2 E 
Condrea, P., and Poenaru, Hélène - 1933. C.r. Séanc. Soc. Biol. Paris, 112,

Dernby, K. G., and Walbum, L. E. - 1923. Biochem. $Z ., 138,505$.

FriedemanN, U., ANd Hollander, A. . 1943. J. Immun., 47, 23.

HALTER, K

VAN HEYNINGEN, W. E. $\quad$. $\quad . \quad$. 1950

ISTRATI, G. . . . . . . 1938.

LARGIER, J. F. . . . . . . 1956.

MALONEY, P. J., AND TAYloR, Edith M. 1932.

MARIE, A. . $\quad . \quad$. $\quad . \quad$. 1914.

Mutermilch, S., Belin, M., AND 1932.

SAlamon, E.

$\quad \quad " \quad \quad, \quad$ " $\quad$ 1933a. Ibid., 113, 599.

" $\quad " \quad$ " $\quad " \quad$ " $\quad 1934 . \quad$ Ibid., 116, 1245.

Pillemer, L. $\quad . \quad$. $\quad . \quad$. $\quad 1946 . \quad$ J. Immun., 53, 237.

Pillemer, L., AND Wartman, W. B. - 1947. Ibid., 55, 277.

Pound, A. W. . $\quad$. $\quad$. $\quad$. $\quad$. 1955. J. Path. Bact., 70, 119.

, . . . . . . . 1958. Ibid., 75, 55.

, . . . . . 1970. Pathology, in press.

Ramon, G., Lémétayer, E., And Nicol, L. 1938a. C.r. Séanc. Soc. Biol. Paris, 127, 1160.

RAMON, G., LémÉtayer, E., Richou, R., $1938 b . \quad$ Ibid., 127, 1157. AND NICOL, L.

Reed, L. J., AND Muench, H. ～～～. 1938. Amer. J. Hyg., 27, 493.

RicketTs, H. T., AND KIrK, E. J. . - 1906. J. Infect. Dis., 3, 116.

Salamon, E., Mutermilch, S., and 1934. C.r. Séanc. Soc. Biol. Paris, 115 BELIN, M.

Smith, Margaret Llewellyn - . 1942-43. Bull. Hith Org. L.O.N., 10, 104.

SOMmer, E. W., AND SOMmer, H. . $\quad$. 1928. J. Infect. Dis., 43, 496.

Traub, F. B., Hollander, A., AND 1946. J. Bact., 52, 169.

FriedemanN, U.

Zuger, B., Hollander, A., ANd Friede- 1939. J. Infect. Dis., 65, 86. MANN, U. 